Eva Wennås Brante

PhD student/Adjunkt, Göteborgs universitet

\title{
Att orientera sig i text och bild. Skillnader mellan förmodad och faktisk läsning för läsare med dyslexi
}

\begin{abstract}
Artikeln presenterar en fallstudie rörande skillnader mellan faktisk och förmodad läsning. För att belysa fallet har tre unga vuxna med dyslexi undersökts då de läst faktatexter med illustrationer varvid deras ögonrörelser spelats in. Deltagarna har även intervjuats kring hur de uppfattar sin läsning. Syftet är att avtäcka eventuella skillnader mellan faktisk och förmodad läsning för denna grupp av läsare då tidigare läsförståelseforskning haft fokus på goda läsare. "Mixed methods" användes vid analys av data. Studiens utgångspunkter är läsning i flera modaliteter, 'the simple view of reading' samt läsförståelse som ett samtidigt processande av delar av texten på flera nivåer. Resultatet, som redovisas i tre narrativ, visar att läsmönstren är delvis omedvetna samt att bilderna betraktas slumpmässigt varvid integrering av information försvåras. Resultatet visar också på problem med avkodning något som försämrar processandet av texten på flera samtidiga nivåer. Resultatet antyder att instruktioner i framförallt bildbearbetning är önskvärt för gruppen av läsare.
\end{abstract}

Keywords: fallstudie, multimedialärande, läsförståelse, mixed methods, ögonrörelser, dyslexi, unga vuxna, narrativ

\section{Inledning}

Att läsa för att förstå en text kräver automatiserad ordavkodning och god språkförståelse hos läsaren (Gough \& Tunmer, 1986; Hoover \& Gough, 1990). Idag, när texter ofta är multimodala, behöver även bilder bearbetas. Poängen med att visa samma information i både text och bild är att ge den läsande möjlighet att verbalisera det visuella samt att visualisera det verbala, för att på så vis nå en förståelse. Inom multimedialärande rubriceras det som att konstruera en mental modell över innehållet (Mayer, 2005). Tidigare studier inom fältet för multimedialärande har visat att människor ofta prioriterar skrift framför bilder (Rayner, Rotello, Stewart, Keir, \& Duffy, 2001; Schmidt-Weigand, Kohnert, \& Glowalla, 2010) men även att de som faktiskt betraktar bilderna presterar bättre på test (Schnotz, Picard, \& Hron, 1993) samt att högpresterande individer i större utsträckning drar nytta av bilder (Hannus \& Hyona, 1999). Bilder som inspekteras är med andra ord en resurs vid skapandet av läsförståelse. Dock, 
mycket av det vi vet om läsförståelse är baserat på studier av skickliga läsare för vilka de grundläggande läsförmågorna är automatiserade (McLaughlin, 2012). I den här artikeln är deltagarna därför respondenter med dyslexi. Artikeln kombinerar intervjuer av respondenterna med tidigare inspelade ögonrörelser från dem (Holmqvist, Nyström, \& Wennås Brante, Unpublished data) till en fallstudie (Yin, 2009) rörande skillnader mellan faktisk och förmodad läsning av faktatexter med bilder integrerade.

Longitudinella fallstudier av personer med dyslexi har utförts av bland annat Hulme och Snowling (1989) och Schneider-Zioga (2012), och då byggt på tester och observationer av individers läsförmåga. Den här studien syftar istället till att åskådliggöra skillnader mellan faktisk och förmodad läsning. Genom att närstudera tre läsare med dyslexi blir det möjligt att upptäcka särdrag som inte går att urskilja på gruppnivå (Schneider-Zioga, 2012), något som är väsentligt då diagnosen dyslexi ger upphov till skilda läsprofiler (Fouganthine, 2012).

\section{Att läsa med förståelse}

Läsförståelse uppstår, enligt 'the simple view of reading', då både hörförståelse och ordavkodning är utvecklade och samspelar (Gough \& Tunmer, 1986; Hoover \& Gough, 1990). Enligt Hoover och Gough (1990) är ordavkodning problematiskt för personer med dyslexi. Den bakomliggande orsaken till svårigheter med automatisk ordigenkänning anses bero på en brist i språkets fonologiska komponent (Everatt \& Reid, 2009; Paulesu et al., 2001). Dessa brister kan finnas kvar upp i vuxen ålder (Kemp, Parrila, \& Kirby, 2009) och bör ej negligeras. Eftersom ordigenkänningen således inte är automatiserad finns det en risk att läsaren gissar sig fram i texten, i stället för att använda sig av underliggande strukturer i texten för att skapa en förståelse (Stanovich, 1986).

Då det inte syns hur det går till när en människa förstår något hon har läst, kräver läsförståelse explicita instruktioner från lärare via modellerande av tankesätt och strategier (Andreassen \& Bråten, 2011; Lundberg \& Reichenberg, 2011; Palinscar \& Brown, 1984). Enligt Rapp och kollegor (2007) går flertalet aktiviteter i interventioner ut på att få elever att fästa uppmärksamheten på utpekade delar av texten. För de läsare som har svårigheter med ordavkodning är uppmärksamheten ofta riktad mot att förstå ord och interventionen skjuter därför ofta över målet. Först när en grundläggande förmåga som ordavkodning är automatiserad kan läsförståelsestrategier bli effektiva (Afflerbach, Pearson, \& Paris, 2008). Trots det bör lärare undervisa om läsförståelsestrategier parallellt med arbetet med att stärka elevers grundläggande färdigheter (Rapp et al., 2007).

\section{En modell av läsförståelse}

Idag betraktas läsförståelse som en meningsskapande aktivitet (McLaughlin, 2012), där läsaren pendlar mellan delar och helhet (Bowden \& Marton, 1998) samtidigt som innehållet kopplas till läsarens förkunskaper. I sin 
läsförståelsemodell beskriver Kintsch och Rawson (2007) läsförståelse som bearbetning av text på flera nivåer;

- mikrostrukturnivå - bokstäver och ord avkodas

- makrostrukturnivå - meningar tillskrivs semantisk innebörd

- textbas-nivå - utläsa explicita budskap från texten

- situationsmodellnivå - en mental bild av innehållet i texten där textens innehåll och budskap ställs i relation till förkunskaper och kritiskt granskas

Genom att urskilja de olika nivåerna och ställa dem i relation till varandra, skapar läsaren en särskild mening. Det går inte att urskilja och relatera delarna till varandra utan att ett meningsskapande sker, precis som att strukturen och nivåerna behövs för att uppfatta meningen på ett djupare plan (Bowden \& Marton, 1998). Förståelsen av en text kan hindras av till exempel brister i ordavkodning, litet ordförråd eller oförmåga att processa delarna i relation till helheten. I de fall texter innehåller bilder kan de bidra till förståelsen på ovanstående nivåer, beroende på bildens och textens utformning. För nybörjarläsaren kan bilden vara ett stöd vid ordavkodning, för den erfarne läsaren kan en inledande bildfixering ge en idé om textens tema (Eitel, Scheiter, \& Schüler, 2010). Enligt Mayer (2009) är ett avgörande moment för förståelsen att en integrering sker av bild och text, det vill säga mellan olika typer av representation av informationen.

Utifrån ovanstående utgångspunkter och med fokus på att beskriva skillnader mellan respondenternas förmodade läsning och deras utförda läsning som den visar sig via ögonrörelser har följande frågor formulerats:

1. Hur medvetna är respondenterna om på vilket sätt de processar texter med bilder?

2. Hur behandlas bilderna och vilken inverkan har de på läsförståelsen?

3. Hur väl lyckas respondenterna med att processa text på flera samtidiga nivåer, det vill säga vilken läsförståelse erhåller de?

\section{Metod}

Data utgörs av intervjuer samt en re-analys av redan insamlade data av ögonrörelser vid läsning av faktatexter om konstgenrer (Holmqvist et al., Unpublished data) och har ställts samman via en så kallad "mixed method" ansats. Ögonrörelsestudien innehöll även svar på läsförståelsefrågor samt resultat från screeningtest avseende fonologisk förmåga. All data har använts för att på olika vis belysa skillnader mellan faktisk och förmodad läsning av texter 
med integrerade bilder. "Mixed methods” innebär att samma forskningsfråga besvaras med olika metoder för att erhålla flera aspekter av det undersökta (Yin, 2006). De olika metoderna har alla använts för att besvara frågorna ovan, men med något olika tyngdpunkter. Fråga 1 har prövats utifrån den information intervjusvaren ger i relation till ögonrörelserna. Vid fråga 2 och 3 har även svaren på muntliga läsförståelsefrågor bidragit med information. Som bakgrund i alla tre frågorna finns poäng på screeningtest gällande fonologisk förmåga med. Resultaten har sammanförts till tre narrativ för att belysa fallet. Nedan beskrivs de olika insamlingsmetoderna samt urval närmare.

\section{Urval}

Artikeln presenterar ett fall belyst av tre respondenter med dyslexi vilka även deltagit i en ögonrörelsestudie (Holmqvist et al., Unpublished data). I den senare deltog 46 personer varav 19 hade dyslexi. För den här artikelns syfte skickades en intervjuförfrågan till gruppen med dyslexi (se figur 1 för urvalsprocess till denna artikel); sex personer besvarade förfrågan. Av dessa sex valdes tre individer ut, vilka uppvisade stor skillnad sinsemellan vad gällde bakgrundsdata som lästid, antal fixeringar samt poäng på läsförståelsefrågor.

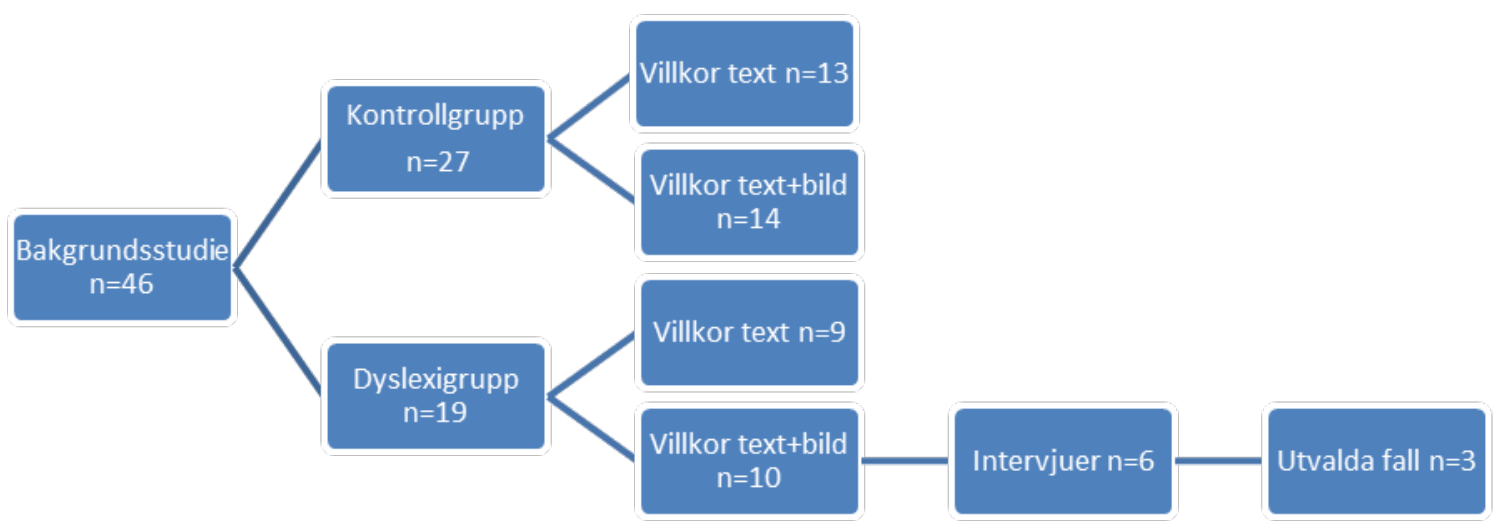

Figur 1. Flödesschema över urval av respondenter 


\section{Intervjuer}

För att öka förståelsen om val bakom placering av blicken samt hur läsning kan upplevas bedömde jag intervjuer som ett passande komplement till ögonrörelsestudien. Intervjuerna genomfördes ett knappt år efter ögonrörelsestudien, och kom därför att behandla respondenternas läsning på en generell nivå. Vid intervjuerna beskrev respondenterna sin läsning utifrån frågor både på detaljnivå och av övergripande art. Intervjuerna genomfördes via telefon och varade cirka en halvtimme. Intervjuerna spelades in efter att samtycke givits.

\section{Ögonrörelsestudie}

Ögonrörelsestudien var genomförd i ett annat sammanhang (Holmqvist et al., Unpublished data). I den här artikeln har en del data återanalyserats med ett nytt fokus. För att underlätta för läsaren ges nedan en kort beskrivning av experimentet vid vilket ögonrörelserna samlades in.

Experimentet beskrev sex olika konstgenrer (se figur 2 för ett exempel) och utfördes i två slumpmässigt tilldelade villkor (se figur 1); enbart text eller med bildexempel till texten.

\footnotetext{
Kubismen var den första abstrakta konststilen på 1900 -talet. Kubisterna var inspirerade av afrikansk

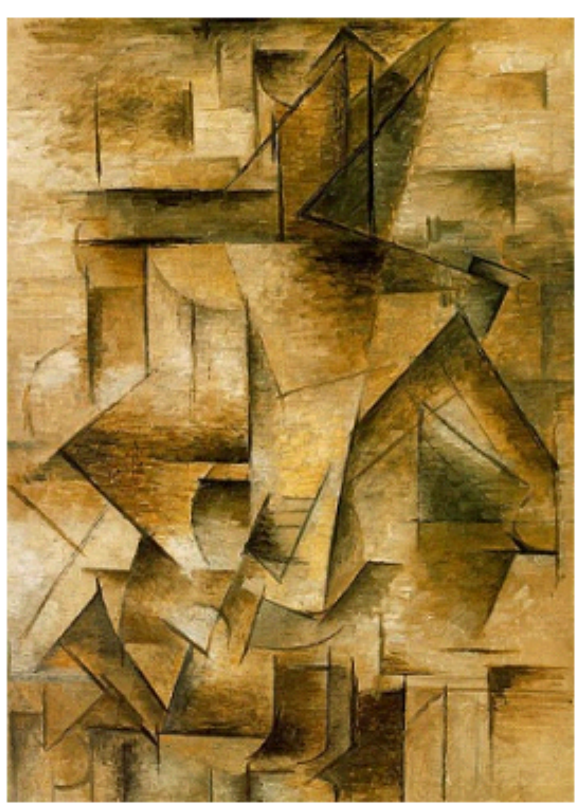

Figur 2. Exempel på text och bild; kubism. 
Ögonrörelserna spelades in i $250 \mathrm{~Hz}$ hastighet med en SMI RED250 eye-tracker och via mjukvaran iView X (v. 2.7.13). Stimuli visades på en 22-inch Dell skärm med upplösningen 1680 x 1050 och presenterades via mjukvaran Experiment Center (v. 3.0. 155). Experimentet genomfördes individuellt och innehöll två delar:

1. Förtest. Sex på varandra följande skärmar visades med uppmaningen att klicka på den bild respondenterna trodde föreställde (aktuell konstart). Tre konstverk att välja mellan.

2. Informationsdel. Varje konstart behandlades enligt följande:

a. Skärm med namn på aktuell konstart.

b. Skärm med antingen bara text kring konstarten eller text+bild. Samma text i båda villkoren.

c. Blank skärm som respondenterna tittade på medan de muntligt besvarade läsförståelsefrågan "Vad fick du veta om (aktuell konstart) på förra skärmen?”

d. Skärm med skriftlig läsförståelsefråga med fyra alternativ.

e. Skärm med fråga "Hur säker var du på ditt svar på förra skärmen?” Svarsalternativ från inte alls säker till helt säker.

f. Skärm med samma uppmaning som i förtestet, samma bilder men i en annan ordning.

A-f upprepades sex gånger. Experimentet avslutades med en fråga kring hur väl respondenterna känt till konstgenrerna sedan tidigare, där svarsalternativen var från "Inte alls” till ”Mycket väl”.

\section{Screeningtest vid ögonrörelsestudien}

Ögonrörelsestudien (Holmqvist et al., Unpublished data) inleddes med screeeningtestet Duvan (Wolff \& Lundberg, 2003) vilket screenar den fonologiska förmågan. Testet består av sex deltest med ett maxpoäng på 290 . Deltest A är självskattning kring läsning. Deltest B fokuserar på arbetsminne och fonologiska minnesfunktioner via memorerande av en bokstavskedja medan deltest $\mathrm{C}$ berör fonologiska representationer och till del fonologiskt minne personerna ska hitta rätt synonym bland ord som låter likadant. Under deltest D ska respondenterna kunna kasta om begynnelseljud, minnas en kort stund vilka ord de då får, därmed testas fonologisk medvetenhet samt arbetsminne. Därefter prövas i deltest $\mathrm{E}$ fonologisk medvetenhet och fonologisk representation genom att respondenterna bland nonsensord ska hitta ett ord som låter som ett riktigt ord om det läses högt. I deltest $\mathrm{F}$ prövas den ortografiska kunskapen genom att respondenterna ska välja rätt stavat ord bland tre, där två är felstavade. 


\section{Analys och bearbetning av data}

Ögonrörelsedata utgörs i huvudsak av tids- och måttsangivelser på fixeringar (ögat står still) och saccader (ögats förflyttning mellan fixeringar), men inspelningen genererar även en "film” över hur ögat rör sig, en så kallad 'scanpath'. För att följa respondenternas väg genom text och bild har jag spelat upp deras 'film' med tio procents hastighet ett flertal gånger. Under uppspelningen har jag fört anteckningar, stoppat och backat, tittat igen och därigenom sett nya saker. Jag har med andra ord behandlat ögonrörelserna som en intervjuutskrift vanligtvis behandlas. Förutom att följa ögonrörelserna har jag jämfört antal fixeringar på text respektive bild liksom om personerna inspekterar bilderna samt i vilket sammanhang de gör det.

Från genomförandet av experimentet fanns också svar på öppna muntliga läsförståelsefrågor. Jag har här använt dem för att undersöka tänkbara samband mellan läsmönster och uttalanden. Det vill säga, är det de ord och meningar som läses ofta, de som läses först eller de som läses sist eller något helt annat som uttrycks i de muntliga svaren?

Under analysen av de tre respondenter som jag valt ut för denna artikels syfte har jag omväxlande fokuserat ögonrörelserna, intervjuerna, de muntliga svaren och screeningtestet. Då respondenterna till exempel berättar om var de börjar läsning i en text har jag prövat om jag kan se evidens eller inte på deras yttrande via ögonrörelser. Jag har också studerat vilka ord respondenterna har fixerat eller helt hoppat över och relaterat det till vad de själva har uttryckt att de har förstått av texten. Min intention har varit att låta ögonrörelser synas och röster höras, något som understryks av den valda redovisningsformen narrativ (Plummer, 2000; Yin, 2011). Narrativen visar hur de tre personernas läsförståelse gestaltade sig men också hur de själva beskriver hur de gör när de läser, det vill säga skillnaden mellan faktisk och förmodad läsning.

\section{Resultat}

För att undvika upprepning av siffror i narrativen ges i tabell 1 en översikt över uppgifter gällande experimenttid, antal fixeringar samt resultat på screeningtestet. Nils ägnar experimentet längst tid, gör flest fixeringar samt har högst poäng på screeningtestet. Cilla ägnar kortast tid åt läsning samt har lägst poäng på screeningtestet. Hon utför färre fixeringar än övriga. Karins lästid, fixeringar och poäng på screening hamnar mellan de övriga två. 


\begin{tabular}{|c|c|c|c|c|c|c|}
\hline & \multirow[t]{2}{*}{ Max } & \multicolumn{2}{|c|}{ Medel } & \multirow[t]{2}{*}{ Nils (29 år) } & \multirow[t]{2}{*}{ Karin (20 år) } & \multirow[t]{2}{*}{ Cilla (21 år) } \\
\hline & & dys & kontr & & & \\
\hline Experimenttid & & $15: 21$ & $12: 44$ & 19:28 min & 16:39 min & 11:06 min \\
\hline Antal fixeringar & 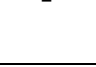 & 2027 & 1667 & 2733 & 1936 & 1152 \\
\hline Poäng på screening & 290 & 125 & 197 & 145 & 128 & 104 \\
\hline
\end{tabular}

Tabell 1. Sammanställning över experimenttid, fixeringar och screeningtest.

Nils, Karins och Cillas delresultat på screeningtestets delar visar på en individuell variation. På deltest D (max 24) har Nils ett lågt resultat på sju poäng, långt under medelvärdet för dyslexigruppen på 13 poäng. Karin är nära medelvärdena för dyslexigruppen på samtliga deltest, medan Cilla hamnar under på deltest A, B, E och F. Cilla har på deltest E (max 60 poäng) endast nio poäng, medelvärdet för kontrollgruppen är här 30.5 samt för dyslexigruppen 17.6. Här följer nu de tre narrativen.

\section{Repetitive läsaren Nils}

Nils är 29 år och han växlar mellan att arbeta och läsa fristående kurser på universitetet. Han beskriver sitt läsproblem som ett avkodningsproblem: "jag har ju bra ordförråd och bra förmåga till att skriva tankar på papper men jag läser bokstav för bokstav och sen ljudar jag fram långa ord”. Korta välkända ord ser han på en gång, vilket bekräftas av uppspelningen av ögonrörelsedatan där korta ord ofta lämnas ofixerade. Han förklarar att han "kan inte se en rad och koda den” utan han tar varje ord för sig, det vill säga att han läser mer sekventiellt än i en helhet. Han säger att han talar texten högt till sig själv inne i huvudet, en vana han vill bryta. Det tar för lång tid när han läser kurslitteratur och "det blir svårt att få ett sammanhang ifall vmeningarna är långa”. Nils beskriver att han " kan börja ganska starkt och känna vad bra det går och sen så hoppar jag, bara läser förbi och sen så inser jag att det här stämmer nog inte riktigt och jag gissar, jag gissar ganska mycket.”

Nils beskriver hur han uppfattar texter:

”när jag får en text... så jag har väldigt svårt och se att det finns information där. Alltså jag ser själva, hur linjerna i texten, hur det estetiska, hur uppbyggnaden är, hur långa är raderna i förhållande till, finns det något mönster där. Tittar på hur mycket vitt finns det till exempel runt texten och bakom. Fast det ser ofta ut som ett stort svart block, då blir det tyngre för mig. För jag har väldigt svårt, det är någonting jag arbetar väldigt mycket med idag, att inte bara se ett stort svart block utan att se 'okej alltså jag måste gå in där, jag måste börja i texten och sen låta mig läsa vad som finns bakom själva bilden'. För, sen, eftersom att jag har sett det här stora, och tittat över hela och sett en bild snarare, så har jag väldigt svårt att läsa uppifrån vänster rakt ner till höger. Så då blir det att jag hoppar ganska mycket fram och tillbaka.” 
Nils beskrivning stämmer med vad ögonrörelserna visar; han läser några ord, han backar i texten och läser om några ord.

\section{Hur läsningen ser ut}

I studien svarar Nils rätt på alla textfrågor och bildfrågor. På förtestet har han fyra rätt av sex. Han uppger själv att han var relativt förtrogen med konstarterna i förväg (rankar sig som fyra på en femgradig skala) och att han varit säker på att han svarat rätt. Eftersom han lyckas svara så här bra på läsförståelsefrågor både i text och i bild-form, vari består då hans lässvårigheter? Det tar Nils drygt 19 minuter att ta sig igenom experimentet och under den tiden utför han 2733 fixeringar. Nils betraktelsemönster är att blicken landar mitt på varje sida mellan texten och bilden, därefter tar han sig via en eller två fixeringar upp till första raden; han börjar sällan med första ordet. Ibland fixerar han sista stavelsen i det ordet, sedan nästa stavelse till vänster tills han läst första ordet. Därefter läser han från vänster till höger, rad för rad. Vid radbyten hamnar han ofta fel, det händer att han läser flera ord på samma rad innan han korrigerar sig till rätt rad. När Nils har läst hela texten på en bildskärm börjar han om igen.

Vid andra och tredje genomläsningen läser han som det på ytan kan tyckas hit och dit och upp och ner, men vid en långsam uppspelning av ögonrörelserna framträder ett annat mönster.

En läsepisod från andra genomläsningen av texten om kubism visar hur Nils först fixerar orden 'konstnären sönderdelade' men istället för att fortsätta meningen går tillbaka på samma rad och fixerar 'uppfattades som mönster';orden hör till meningen innan men i samband med 'konstnären sönderdelade' ger orden mening eftersom något sönderdelat kan bli ett mönster. Läsningen fortsätter uppåt och åt olika håll med orden tavlorna - former naturen - hjälp av - cylindern - cirkeln - konstnären sönderdelade motivet i en mängd små geometriska former. Hela kedjan blir: konstnären sönderdelade uppfattades som mönster - tavlorna - former - naturen - hjälp av - cylindern cirkeln - konstnären sönderdelade motivet i en mängd små geometriska former.

Läsepisoden varar cirka sex sekunder. När Nils sist i läsepisoden läser en hel mening har han sannolikt förstärkt förståelsen av meningen genom att påminna sig om vad det var för former som konstnären sönderdelade motiven i (cylindrar och cirklar) och vilka motiv man hade (naturen). Informationen återkommer i hans muntliga svar som " man avbildade landskap och kroppar med geometriska figurer, man gjorde ofta, man kanske gjorde det med mindre kroppar".

En svårighet i Nils förståelse av texten verkar ha utgjorts av orden 'flersidiga kroppar' som förekommer relativt nära ordet 'människor'. Han fixerar ordet flersidiga ett flertal gånger, men ordet återkommer inte i hans muntliga svar. Kroppar nämner han dock två gånger. Första gången är när han säger att "man avbildade landskap och kroppar". I texten står det människor; att han säger kroppar framstår som logiskt då ordet kroppar står i närheten och en människa är 
en kropp. Om vi inte avbildar själva kroppen, vad avbildar vi då? Och vad hade han sagt om ordet kroppar inte hade funnits i texten? Lite längre fram säger Nils (apropå att sönderdela motivet) att "man kanske gjordet det med mindre kroppar”. Det är möjligt att han där tänker att en cylinder är en kropp, eller så är det formuleringen från texten 'flersidiga kroppar' som ger avtryck. En scan-path (figur 3) från Nils läsning av texten om kubism visar vilka delar av texten han har fixerat mest.

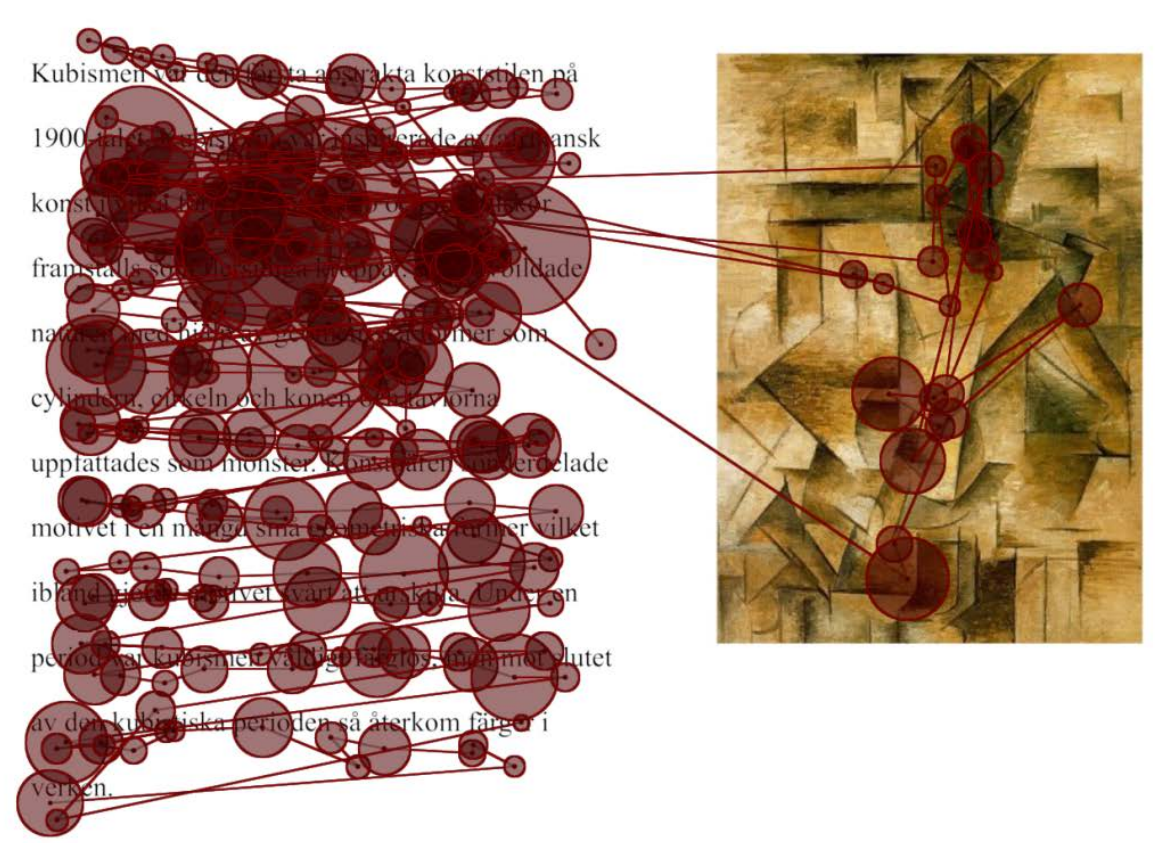

Figur 3. Scan-path över Nils fixeringar; kubismen.

Den sista meningen innehåller en kontrast mellan två påståenden - färgrikt och färglöst. Kontraster är verkningsfulla då det gäller att fånga uppmärksamheten, vilket Nils visar genom att nämna informationen i sitt svar "det kunde vara ganska färglösa bilder men i slutet så blev dom mer färgrika”. Detta trots den sista meningen har få fixeringar jämfört med den första. Scan-pathen visar även att det inte går att dra enkla slutsatser om förståelse utifrån enbart antal fixeringar. 'Flersidiga' har fixerats så många gånger att ordet inte går att urskilja i figur 1, men Nils har ändå inte 'löst' ordet.

\section{Bilder}

Första gången Nils inspekterar bilden är när han vid första genomläsningen kommer till ordet människor på tredje raden. Ett antagande är att han inte har uppfattat konstverket (via det perifera synfältet) som föreställande en människa och därför placerar en fixering på bilden efter att ha läst ordet människor. Omedelbart därefter fixerar Nils återigen ordet människor och därpå fixerar han det man kan uppfatta som ett huvud på bilden. Först när han har läst igenom hela 
texten återvänder han till bilden, varvid han placerar 23 fixeringar på den. Mönstret stämmer med Nils beskrivning av hur han brukar göra, inspektera bilder ordentligt när han har läst klart en sida.

\section{Tidsaspekter}

Under intervjun nämner Nils den tidspress han upplever vid läsning: ”jag vet att jag försöker skynda mig som tusan, det är ingen som tar hänsyn, om man märker att de flesta är klara, då är det ingen som väntar på mig.”

När experimentet genomförs finns inga andra respondenter att jämföra sig med, men Nils berättar att han har upplevt situationen som pressande. Nils läser en sida förhållandevis snabbt, men återvänder sedan till början och läser om hela texten en till två gånger. Det framstår därför som att om det är vid omläsningen som de meningsskapande läsepisoderna uppstår. Å andra sidan vet vi inte hur han hade förstått texten om han hade läst långsammare.

\section{Noggranna läsaren Karin}

Karin är 20 år och läser till lärare vid ett universitet. I hennes familj finns flera släktingar med dyslexi, så när Karin som liten visade på en långsam start $\mathrm{i}$ läsinlärningen var hennes mamma förberedd. I lågstadiet kände Karin inte igen ord automatiskt: "alla andra läste orden medan jag läste bokstaven och jag var tvungen att ljuda varje bokstav". Under skolgången fick hon gå hos en specialpedagog för att hennes lärare inte kunde hantera henne. Karin säger: "jag var för svår att kunna hantera samtidigt med resten av klassen. Och sen så, när jag kom upp i trean till femman så trodde de att jag var psykiskt sjuk och hade stora aggressioner." Först i årskurs fem gjordes en dyslexiutredning. Karin minns det som att hon "blev i princip mobbad av mina lärare för att jag inte låg på samma nivå som alla andra”.

\section{Hur läsningen ser ut}

När Karin ser ett nytt ord så "vet jag inte hur bokstäverna ska låta och måste pröva mig fram". Med andra ord, när Karin möter ett ord som är nytt för henne så har hon inget ortografiskt minne av det, inget att hänga upp förståelsen på.

Vid ögonrörelsestudien läser Karin väldigt systematiskt, rad för rad, med en del regressioner både i ord och mellan ord. När Karin avkodar ett längre ord gör hon det med några fixeringar och går sedan vidare till nästa ord men när hon väl är några ord fram så återvänder hon och fixerar det första ordet några gånger till. Det är ett exempel på den strategi hon har berättat att hon har för att få mening i faktatexter: ”Jag läser ord på ord, och så tar jag ihop det till en mening så att jag ska få en djupare insikt i vad jag läser.” Detta ska ställas i kontrast till hur Karin upplever att hon läser en skönlitterär text då "flyter det på ett helt annat sätt. Jag läser meningar i helhet istället för att jag måste förstå ord för ord”. Såväl Karins beskrivning som hennes ögonrörelser visar att hon inte förstår alla ord vid första fixeringen. Det är ytterst få ord som Karin fixerar enbart en gång, något som är 
mycket vanligt i kontrollgruppen. Ett ord som "sönderdelade", en sammansättning av två vanliga svenska ord, fixerar Karin sex gånger, till skillnad från kontrollgruppens en till två gånger. Karin säger också att alla ord hon läser blir till bilder: "säg att det står "katt”, då ser jag en katt. För jag läser inte bokstäverna utan jag ser bilden på ordet katt och så ser jag då en katt”. När det gäller vanligt förekommande ord, som är mera abstrakta, "då är bilden ordet på sidan”. Karin säger: "eftersom jag ser bilder hela tiden så är det ju liksom ett dubbelt arbete i kroppen."

I Karins läsning kan vi också se ett exempel på hur ett ord blir välkänt efter ett antal fixeringar. Ordet impressionism möter hon i förtestet, i en rubrik, därefter två gånger i själva texten om impressionism för att till sist möta ordet igen i bildfrågan. De fyra första gångerna Karin möter ordet fixerar hon det stavelse för stavelse. Femte gången placerar hon endast en fixering på ordet. Det framstår som om Karin nu har skapat sig en ordbild av "impressionism” och därmed har det blivit möjligt att automatiserat hämta ordet från det ortografiska minnet.

Karin läser som sagt noggrant, rad för rad, även om hon ibland vid radbyte hamnar på fel rad. Hon fixerar ofta stavelse för stavelse och läser om många ord ett flertal gånger men har ändå cirka 1000 färre fixeringar än Nils. Karin tar sig igenom texten en gång, sen läser hon om på några ställen. I texten om kubism läser hon i huvudsak om mening två som är en innehållsrik mening. Det finns en stor överensstämmelse mellan Karins omläsning och hennes muntliga svar. De ord hon landar på i omläsningen (se figur 4) är: vilka - 1900-talet - kubisterna föremål - landskap - afrikansk - framställs - föremål - landskap - människor man avbildade. Hon förflyttar blicken ner mot 'geometriska former. (Här har inspelningen förlorat data, då det inte syns någon saccad inför sista fixeringen, vilken landar mellan 'konen' och 'tavlorna'). Det muntliga svaret är "Kubismen är en konstart där man under 1900-talet tog olika motiv som människor, landskap, djur, ja det mesta, och tog bilden och gjorde den i geometriska former, till exempel koner, cirklar, fyrkanter”. Att Karin införlivar djur i beskrivningen av motiv kan bygga på egna tidigare erfarenheter eller helt enkelt att hon tycker det är rimligt. En tänkbar förklaring är att ordet afrikansk leder associationer till vilda djur. Ordet fyrkanter finns inte med i texten, men är också ett vardagligare uttryck för en geometrisk form som också syns på bilden och möjligen lättare att minnas på så vis. 


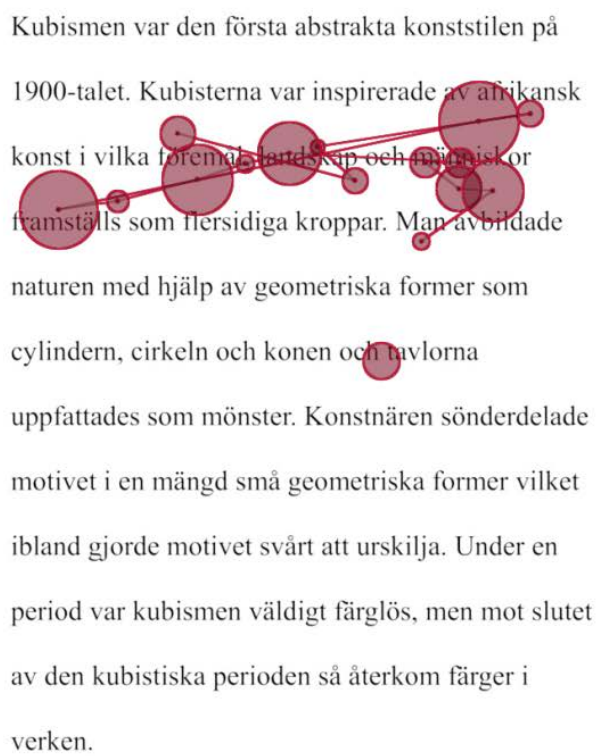

Kubismen var den första abstrakta konststilen på

naturen med hjälp av geometriska former som

cylindern, cirkeln och konen ochngulorna

uppfattades som mönster. Konstnären sönderdelade

motivet i en mängd små geometriska former vilket

ibland gjorde motivet svårt att urskilja. Under en

period var kubismen väldigt färglös, men mot slutet

verken.

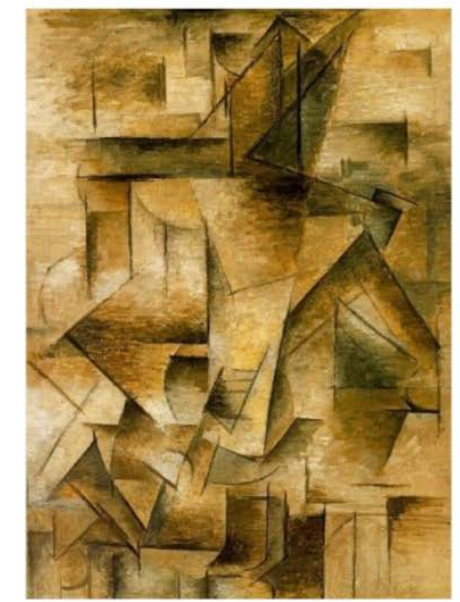

Figur 4. Scanpath över Karins omläsning.

\section{Bilder}

På förtestet som består av bilder prickar Karin in ett rätt av sex. Efter att ha läst om konstgenrerna och sett bildexempel får hon ändå inte mer än tre rätt av sex. Hon uppger själv att hon känner sig mycket förtrogen med konstgenrerna sedan tidigare. Vid skärmarna om Romantiken och abstrakt konst fixerar Karin enbart på texten, men kan ändå beskriva bilderna. Hon beskriver dessutom detaljer från motivet. I intervjun nämner Karin att hon har jobbat med att öva upp sitt bildminne, till den grad att andra har sagt att hon har ett fotografiskt minne. Hon uppger också att hennes strategi när hon möter text och bild är att först inspektera bilden. Bilden ger henne en slags bakgrund som hon sen kan starta läsningen med. Under experimentet underlåter hon trots detta att titta på tre av sex bilder, övriga tittar hon på först någon gång mitt under läsningen. Trots hennes uttalande om bildminne och trots att hon själv uppger att hon känner sig väl förtrogen med konstgenrerna sedan tidigare så erhåller Karin som sagt endast tre rätt av sex på bildfrågan.

\section{Olika texttyper}

I slutet av intervjuen reflekterar Karin över skillnaden i hur hon läser olika texttyper. Faktatexter läser hon ibland högt som en strategi, då hon känner att hon måste förstå varje ord för att få en mening. Karin jämför vidare:

”läser jag en skönlitterär text så är det ju jag som vill, jag läser den för att den ska betyda något för mig. Och jag relaterar den till mig själv hela tiden. Medan när jag läser en faktatext så är det ju på något sätt ett studie-jag, som jag relaterar till. Då 
måste jag koppla ihop den med hela världsbilden. Det känns som om man har ett litet lexikon i sitt huvud som man hela tiden, åh, men det där, det hänger ihop med det som hände där borta i historien någonstans. Ja det gjorde det nog”.

Vid faktaläsning arbetar Karin aktivt med sin textförståelse genom att integrera tidigare kunskaper med det hon läser just nu, men känner samtidigt att hon är en annan person vid den sortens läsning.

\section{Snabbläsaren Cilla}

Cilla är 21 år och har läst in gymnasiekompetens på en folkhögskola, med syfte att utbilda sig till förskollärare. Cilla säger att det är tufft för henne med en ny typ av texter och ord. Hon fortsätter: "ord som jag inte känner igen, jag vet inte hur jag ska uttala det heller så om jag försöker läsa högt så vet jag inte riktigt hur jag ska säga det”. De nya ord hon möter i utbildningen får på så vis ingen mening. Cillas strategi är bland annat att använda sig av www.synonymer.se för att se om en förklaring av ordet och en uppläsning av det hjälper henne att ge det en mening. Svårigheten att koppla ett okänt ord till ljud och höra det inuti huvudet är en möjlig förklaring till hennes låga resultat på Duvans deltest E, där man ska läsa felstavade ord blandade med nonsensord för att höra vilka som är de riktiga orden. De felstavade orden ser inte bekanta ut och resultatet på deltestet visar att Cilla inte verkar höra vilka som är riktiga ord. Cilla beskriver läsning som att försöka ta sig igenom en gelé-vägg. Efter flera försök är hon kanske halvvägs. När Cilla var liten hade hon ett talfel (oklart vilket) men som påverkade hennes språkutveckling. Ljud har varit svåra att forma och att känna igen. Fortfarande, idag, kan hon ha svårt att uttala vissa ord. Hon säger "jag har ju vissa ord som jag säger, som jag själv tycker jag säger rätt i huvudet, men andra säger att jag inte säger rätt”.

\section{Hur läsningen ser ut}

Cilla ägnar kort tid åt experimentet, lite mer än elva minuter jämfört med Nils dryga 19 och Karins 16 och en halv minuter. Den snabba läsningen sker på bekostnad av att inte alla ord blir fixerade; ibland är till och med en hel rad utan en enda fixering. Första meningen i en text är ofta informationsrik. Det är därför intressant att se att Cilla inte fixerar alls på den första raden vid flera av skärmarna som hon inspekterar. Texten om impressionism har exempelvis ingen fixering alls på första raden och endast sparsamt på andra raden. Inte ens när Cilla läser om delar av texten om impressionism fixerar hon på första raden, trots att tyngdpunkten i hennes omläsning ligger på den övre texthalvan. När Cilla berättar om sin läsning säger hon: ”jag börjar längst ut och ibland så kollar jag längst ner, jag brukar kolla liksom sidorna, omläsa lite successivt.” Med längst ut menar hon förmodligen att hon börjar längst ut i vänsterkanten, vilket inte stämmer med de ögonrörelser som är inspelade. Däremot läser hon relativt rakt igenom en text innan hon går tillbaka och läser om, med det särdraget att hon ofta hoppar över flera ord. 
Figur 5 visar att Cilla lämnar mer än halva första raden ofixerad och att hon hoppar över flera ord några rader från slutet. Överhuvudtaget är det långt mellan fixeringarna mot slutet. Totalt sett under hela experimentet gör Cilla färre fixeringar (1152 st) än både Nils (2733 st) och Karin (1936 st), till och med långt under kontrollgruppens medelvärde på fixeringar (1667 st). Hennes muntliga svar är kortfattade och till och med en del felaktiga uppfattningar. Vad det gäller pop-art så säger hon efter att ha läst texten och tittat på bilden (två korta fixeringar) att "det skapades i England och i USA och att man använde vardagliga saker och att oftast gjorde det mångproducerat". Här har Cilla blandat ihop två informationsled; i texten står att man använder sig av massproducerade föremål som en kontrast mot finkonsten. De vardagliga föremål som finns på bilden, soppburkar, kan antas ha lett hennes tankar mot ordet vardagliga.

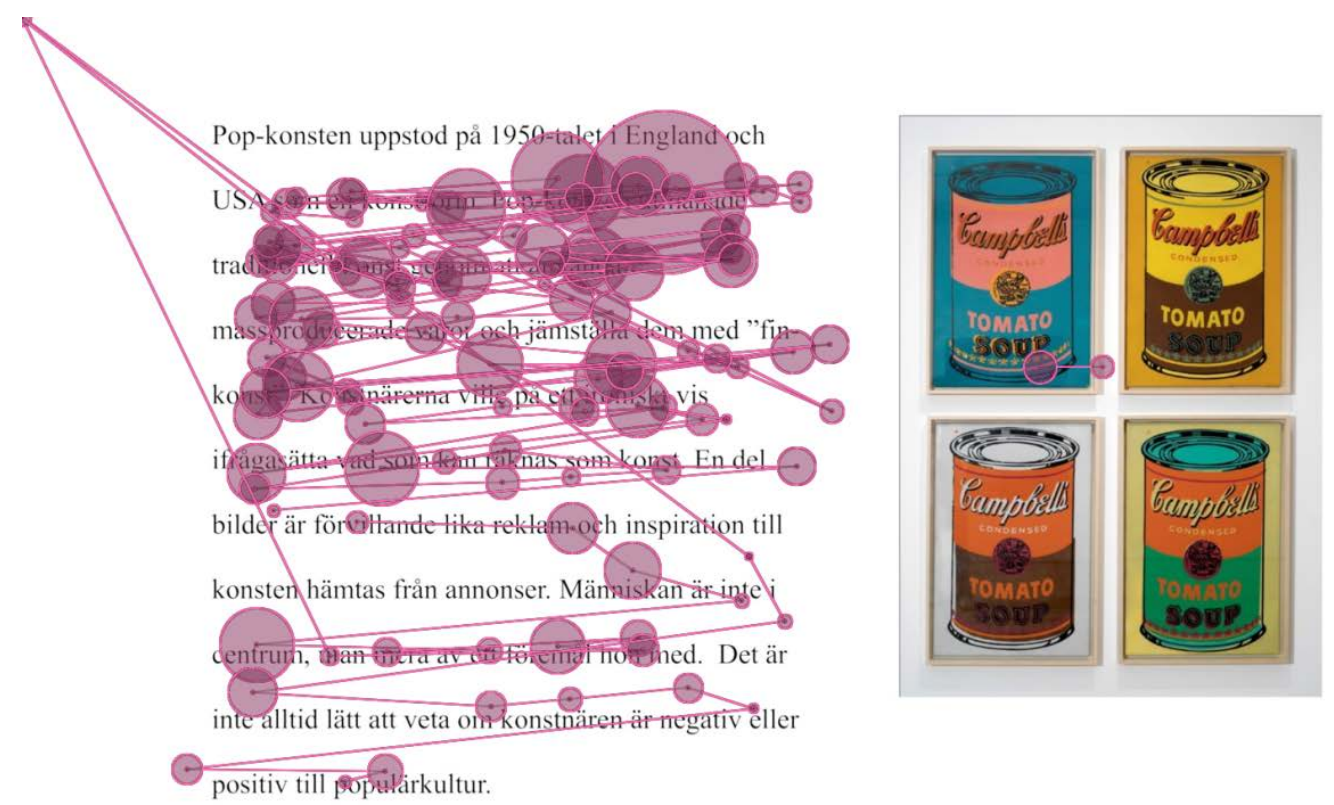

Figur 5. Scanpath från Cilla över text och bild om pop-art.

\section{Bilder}

Cilla säger i intervjun att hon ofta tittar på en bild först för att se om den kan ge någon mera information av intresse, annars struntar hon $\mathrm{i}$ den. Ögonrörelseinspelningen visar att hon vid läsningen av två av sex skärmar tittar snabbt in i bilderna precis i början av att skärmen presenterats, för att sedan inte återvända till dem igen. Bilderna, exempel på impressionism och kubism, får en fixering var. Gemensamt för dem är att de är diffusa i motiv och flyter samman mer än övriga konstverk. En bild som däremot har fångat hennes uppmärksamhet är illustrationen till surrealism, som hon återvänder till tre gånger med sammanlagt tio fixeringar. Hennes fixeringar är längre här (363 ms) 
än genomsnittets (213 ms). Den surrealistiska bilden föreställer föremål som inte passar ihop; liknande information men med en motivering finns i texten. Den första fixeringen i bilden är andra totalt på skärmen, och den placeras nära en figurs öga för att därefter fixera en hatt på samma figur. Efter att ha läst klart hela texten (utom första raden) går hon tillbaka till bilden och fixerar flera gånger mellan två punkter som kan beskrivas som en snabel på ovan nämnda figur, därefter en lång fixering på en huvudlös kvinnokropp och så på hatten på figuren igen. Hon läser sedan om en mening i texten som beskriver att surrealistiskt måleri gick ut på att ta sig förbi logiken för att låta det undermedvetna styra hur föremål kombineras. Sen avslutar hon med ännu en fixering på det som liknar en snabel.

Trots att Cilla här har möjlighet att skapa sig en situationsmodell av surrealismen genom dels bilden, som hon fixerar flera gånger, och texten där hon faktiskt läser om en strategisk mening, så speglas ingen djupare förståelse i det muntliga svaret. Hon säger "att det startades på 1920-talet, och att man, den konsten är att man blandar olika föremål i bilden så att, mm, ja, jag stannar där”. Cilla tolkar vad av texten som passar ihop med bilden, men får inte med någon förklaring till konstgenrens motiv att sätta samman föremål från olika håll. Cilla läsning kan närmast beskrivs som rapsodisk . Då hon missat en hel del ord är det förmodligen svårare för henne att föra samman nyckelord till meningsbärande enheter.

\section{Diskussion}

De tre narrativen är sammanställda för att belysa fallet om det finns skillnader mellan faktisk och förmodad läsning vad gäller faktatexter med bilder integrerade. Respondenterna har på grund av sin diagnos (dyslexi) tänkt mycket på hur de läser, vilket gör att skillnader mellan utförande och vad respondenterna säger sig göra är relativt små. Skillnader förekommer bland annat vid hanterandet av bilder i texter, vilket exemplifieras nedan.

Nils beskriver ett textdrivet läsande där han startar med textläsning, när en sida är läst tittar han på eventuella bilder. Nils ögonrörelser visar att han inte är helt konsekvent i sitt agerande. Ögonrörelsemönstret från kubismen förevisar att han tidigt i läsandet får en impuls att titta på bilden utifrån ordet "människor" då bilden kontrasterar mot texten. Tidigare resultat från studier av multimediadesign har demonstrerat att ett vanligt tillvägagångssätt är kort läsning av text därefter inspektion av bild (Rayner et al., 2001), även om det finns de som väntar med bildinspektion till sist också (Schmidt-Weigand et al., 2010). Nils borde starta med att inspektera bilden, då han på så vis skulle erhålla en möjlighet till en (om än rudimentär) helhetsuppfattning (Marton \& Booth, 1997) av det han ska läsa. Därefter kan han inspektera ytterligare delar för differentiera den första helhetsuppfattningen. 
Karin uppger att hon alltid börjar med att titta på en bild för att skapa en bakgrund till läsningen. Ögonrörelseinspelningen visar att hon helt negligerar tre av sex bilder, övriga tre tittar hon på först efter ett tag. Hon försitter på så vis möjligheten att starta med den helhetsuppfattning hon säger sig eftersträva. Då texten och bilden i experimentet är presenterade på en skärm har respondenterna möjlighet att uppfatta bilden även ur sitt perifera synfält (Holmqvist et al., 2011), något Karins narrativ bekräftar. Hon har inte fixerat tre av bilderna alls, men kan återge motiven ändå. Det kan tyckas motsägelsefullt, men ett första intryck av en bild fångar vi upp snabbare än vi är medvetna om. En studie genomförd av Eitel et al (2012) visar att bilder exponerade 600 millisekunder räckte för att påverka lärandet i positiv riktning. En sådan kort exponering ger dock bara en väldigt översiktlig förståelse. För att fördjupa förståelsen behöver bilden utforskas ytterligare via flera fixeringar. Både läsförståelsemodellen av Kintsch och Rawson (2007) och Mayer's teori om effektiv multimediadesign pekar på på betydelsen ett samtidigt processande. I det första fallet gäller att nivåerna av textbearbetning bör ske simultant, i det andra fallet att ny kunskap ska integreras med befintlig. Eftersom Karin endast fixerar på bilderna kort tid eller inte alls minskar hennes möjlighet att konstruera en mental modell eller en situationsmodell över det hon läser, vilket också visar sig i hennes kortfattade muntliga läsförståelsesvar.

Cilla uppger att hon gärna startar med att titta på bilderna, för att värdera om hon kan ha nytta av dem. Eftersom experimentets texter består av information om konstgenrer, hade det varit särskilt värdefullt att ta sig tid att titta på exemplen från de olika konstgenrerna. Antingen bedömer Cilla bilderna som utan information, eller så är hon mera impulsdriven än vad hon säger sig vara. De bilder hon helt förbiser har diffusa motiv, medan hon placerar flera fixeringar på den tydliga surrealistiska bilden. Här skulle hon ha haft möjlighet att skapa sig en djupare förståelse, men, som Mayer uttryckt det (2005) är det viktigt både att text visualiseras och att illustrationer verbaliseras. Då Cilla läser snabbt och hoppar över en mängd ord, ger det henne ett svagt underlag för att verbalisera det hon ser i bilden. Hon har på så vis inte integrerat text med bild, vilket också visar sig i hennes korta och ytliga svar på den muntliga läsförståelsefrågan.

Vad gäller ordavkodning visar resultaten snarare samstämmighet än skillnad mellan faktisk och förmodad läsning. Respondenterna rapporterar alla om hur de hela tiden tänker aktivt på hur de ska förstå texten på en ordnivå . Detta bekräftas av ögonrörelsemätningarna, då förhållandevis enkla ord som'sönderdelade' eller 'flersidiga' blir fixerade en mängd gånger. Om ord ljudas bokstav för bokstav uppnås inte förståelse; personer måste höra vilket ord som bildas (Pressley, 2001). De två förmågorna ordavkodning och hörförståelse verkar inte jämnstarka (Hoover \& Gough, 1990), så istället för att skapa en helhet av texten tvingas respondenterna att arbeta med att avkoda den ord för ord. Den bristande avkodningsförmågan tar på så vis fokus från processer som 
behövts för att nå läsförståelse, som att koppla det lästa till tidigare kunskaper, urskilja teman i texten med mera (Kintsch \& Rawson, 2007). Det händer att läsare med bristande avkodning rör sig med en förståelse enbart grundad på de sammanhang som syns på ytan av en text; de djupare strukturerna i texten förblir oupptäckta (Stanovich, 1986). Det blir tydligt i exempelvis Cillas svar gällande pop-art, där hon visar att hon avläst nyckelord men inte hittat det egentliga budskapet.

\section{Slutord}

Uppspelningar av ögonrörelser har tidigare visat sig ge metakognitiva vinster (Hyrskykari, Ovaska, Majaranta, Räihä, \& Lehtinen, 2008). Respondenterna i denna studie hoppade över ord, läste för fort och tvingades läsa om samt undvek bildinformation. Finns det pedagogiska vinster av att använda ögonrörelseinspelningar i syfte att medvetandegöra personer om deras läsning? Vidare forskning kring ifall ögonrörelseinspelningar kan förändra läsmönster gällande exempelvis vid vilken tidpunkt bilder betraktas eller läshastighet skulle bidra med information kring möjligheten att använda ögonrörelseinspelningar som en pedagogisk utvecklingsmetod.

\section{Studiens begränsningar}

Fallet skillnad mellan faktisk och förmodad läsning belyses här av ett litet urval vilket gör resultatet specifikt snarare än generaliserbart. Valet att i detalj beskriva få personers läsning ger dock kunskap om hur olika läsning gestaltar sig för personer med samma diagnos. En annan begränsning är att läsningen skett $\mathrm{i}$ en experimentell situation, där den för läsning så viktiga motivationen saknats (Guthrie, Wigfield, Metsala, \& Cox, 1999). Motivationen bestod snarast av att deltaga i studie och intervjuer.

\section{Referenser}

Afflerbach, P., Pearson, P. D., \& Paris, S. G. (2008). Clarifying differences between reading skills and reading strategies. The Reading Teacher, 61(5), 364-373.

Andreassen, R., \& Bråten, I. (2011). Implementation and effects of explicit reading comprehension instruction in fifth-grade classrooms. Learning and Instruction, 21(4), 520-537.

Bowden, J., \& Marton, F. (1998). The university of learning. London: Kogan Page.

Eitel, A., Scheiter, K., \& Schüler, A. (2010). Getting a clue: gist extraction from scenes and causal systems. Diagrammatic Representation and Inference (243-249). Tübinger: Knowledge Research Center.

Eitel, A., Scheiter, K., Schüler, A., Nyström, M., \& Holmqvist, K. (2012). How a Picture Can Scaffold Comprehension of Text. Paper presenterat vid EARLI SIG 2-meeting, 28-31 augusti 2012, Grenoble, France.

Everatt, J., \& Reid, G. (2009). Dyslexia: An overview of recent research. I G. Reid (Red.), The Routledge Companion to Dyslexia (s. 3-21). London: Routledge. 
Fouganthine, A. (2012). Dyslexi genom livet: Ett utvecklingsperspektiv på läs-och skrivsvårigheter. (Doctoral dissertation). Stockholm: Stockholms universitet, Stockholm.

Gough, P., \& Tunmer, W. (1986). Decoding, reading, and reading disability. Remedial and special education, 7(1), 6-10.

Guthrie, J. T., Wigfield, A., Metsala, J. L., \& Cox, K. E. (1999). Motivational and cognitive predictors of text comprehension and reading amount. Scientific Studies of reading, 3(3), 231-256.

Hannus, M., \& Hyona, J. (1999). Utilization of illustrations during learning of science textbook passages among low-and high-ability children. Contemporary Educational Psychology, 24(2), 95-123.

Holmqvist, K., Nyström, M., Andersson, R., Dewhurst, R., Halszka, J., \& van de Weijer, J. (2011). Eye tracking: A comprehensive guide to methods and measures. Oxord: Oxford University Press.

Holmqvist, M., Nyström, M., \& Wennås Brante, E. (2013). Text and picture revisited. Unpublished raw data.

Hoover, W., \& Gough, P. (1990). The simple view of reading. Reading and Writing, 2(2), 127-160.

Hyrskykari, A., Ovaska, S., Majaranta, P., Räihä, K.-J., \& Lehtinen, M. (2008). Gaze path stimulation in retrospective think-aloud. Journal of Eye Movement Research, 2(4), 1-18.

Kemp, N., Parrila, R. K., \& Kirby, J. R. (2009). Phonological and orthographic spelling in high-functioning adult dyslexics. Dyslexia, 15(2), 105-128.

Kintsch, W., \& Rawson, K. (2007). Comprehension. In M. J. Snowling \& C. Hulme (Eds.), The science of reading: A handbook (s. 209-226). Malden, MA: Blackwell publishing.

Lundberg, I., \& Reichenberg, M. (2011). Developing reading comprehension among students with mild intellectual disabilities: An intervention study. Scandinavian Journal of Educational Research, 57(1), 89-100.

Marton, F., \& Booth, S. (1997). Learning and awareness. Mahwah, N.J.: Lawrence Erlbaum.

Mayer, R. (2005). Cognitive theory of multimedia learning. I R. Mayer (Red.), The Cambridge handbook of multimedia learning (s. 31-48).

Mayer, R. (2009). Multimedia principle. In R. Mayer (Red.), Multimedia learning (2nd ed.) (pp. 223-241). New York, NY: Cambridge University Press.

McLaughlin, M. (2012). Reading comprehension: What every teacher needs to know. The Reading Teacher, 65(7), 432-440.

Palinscar, A. S., \& Brown, A. L. (1984). Reciprocal teaching of comprehension-fostering and comprehension-monitoring activities. Cognition and instruction, 1(2), 117-175.

Paulesu, E., Démonet, J. F., Fazio, F., McCrory, E., Chanoine, V., Brunswick, N., . . Frith, C. D. (2001). Dyslexia: cultural diversity and biological unity. Science, 291, 2165-2167.

Plummer, K. (2000). Documents of life 2: An invitation to a critical humanism. London: SAGE.

Pressley, M. (2001). Comprehension instruction: What makes sense now, what might make sense soon. Reading Online, 5(2), 1-14.

Rapp, D. N., Broek, P. v. d., McMaster, K. L., Kendeou, P., \& Espin, C. A. (2007). Higherorder comprehension processes in struggling readers: A perspective for research and intervention. Scientific Studies of reading, 11(4), 289-312.

Rayner, K., Rotello, C. M., Stewart, A. J., Keir, J., \& Duffy, S. A. (2001). Integrating Text and Pictorial Information: Eye Movements When Looking at Print Advertisements. Journal of Experimental Psychology: Applied, 7(3), 219-226.

Schmidt-Weigand, F., Kohnert, A., \& Glowalla, U. (2010). A closer look at split visual attention in system-and self-paced instruction in multimedia learning. Learning and Instruction, 20(2), 100-110. 
Schneider-Zioga, P. (2012). Phonological precedence in dyslexia: A case study. Language Acquisition, 19(3), 183-222.

Schnotz, W., Picard, E., \& Hron, A. (1993). How do successful and unsuccessful learners use texts and graphics? Learning and Instruction, 3(3), 181-199.

Snowling, M., \& Hulme, C. (1989). A longitudinal case study of developmental phonological dyslexia. Cognitive Neuropsychology, 6(4), 379-401.

Stanovich, K. (1986). Matthew effects in reading: Some consequences of individual differences in the acquisition of literacy. Reading Research Quarterly, 21(4), 360-407.

Wolff, U., \& Lundberg, I. (2003). A technique for group screening of dyslexia among adults. Annals of Dyslexia, 53, 324-339.

Yin, R. K. (2006). Mixed methods research: Are the methods genuinely integrated or merely parallel. Research in the Schools, 13(1), 41-47.

Yin, R. K. (2009). Case study research: Design and methods (4 ed.). London: SAGE.

Yin, R. K. (2011). Qualitative research from start to finish. New York: Guilford Press. 